\title{
パワーセンター開業による消費行動の分析と商業地選択モデルの作成 Analyze of Consumer's Behavior and Make a Shopping District Choice Model considering an effect of Power Center
}

\author{
湯沢 昭*・渡辺愛子**・須田 熙***
}

Akira YUZAWA, Aiko WATANABE and Hiroshi SUDA

1. はじめに

モータリゼーションの進展による道路整備の充実や 商業施設の出店形態の変化などが各地で見られるよう になってきた。その結果，従来は駅前周辺の商店街を 中心に繰り広げられてきた商業活動は，最近では幹線 道路沿線を中心として展開されつつある.中でも複数 の大規模店舗の集合体であるパワーセンターと呼ばれ る商業施設が各地域に整備されている。大規模商業施 設の立地は，利用者である消費者の購買行動に大きな 影響を与え，また消費行動の変化が商業施設の立地に 対しても影響を与えることになる．このような傾向は 特に地方都市で顕著であり, 都心部の商業活動の地盤 沈下が大きな問題となっている．浅野等は ${ }^{1)}$ ，長野県 を事例として郊外型大規模店舗の出店傾向やその分布 について土地利用規制との関連を中心に分析を行って

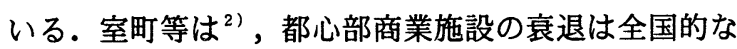
傾向であり，大規模小売店舗の立地は，環状線や放射 線道路，バイパス等にその立地が多く見られるとの分 析を行っている.

本研究は, 郊外型大規模店舗の立地が消費行動に与 える影響を分析し，その結果をもとに商業地選択モデ ルの作成を行い，次のようなことを明らかとすること を目的としている.

(1)消費行動に関する意識構造分析から，性別・年代 別，家族構成別の消費構造を明確にする.

(2)品目別の商業地選択モデルの結果から, 従来の都 心部の商店街と郊外型大規模店舗の差別化の可能性に

キーワーズ:パワーセンター, 消費行動, 商業地選択モデル

*正会員 工博 長岡工業高等専門学校環境都市工学科 教授 (F940 長岡市西片貝町888 tel0258-34-9271,fax34-9284) **新潟県上越市役所都市整備部都市計画課 技師 ***正会員 工博 八戸工業大学工学部 教授
ついて分析を行い，今後の都心部の商店街のあり方 について検討を行う。

なお，事例研究としては，新渴県上越市を取り上げ， 従来の商店街としては，同市の都心部である「高田駅 前」を, 郊外型大規模店舗としては，パワーセンター である「上越ウイングマーケットセンター」を調査対 象とし分析を行う。

\section{2. 調查の概要}

図ー 1 は, 調查対象地である上越市の大規模店舗 （第一種と第二種大規模小売店舗）の立地状況を示し たものであり，特に幹線道路沿線の店舗の立地は，そ の多くが1993年以降に営業を開始していることが分か る.これは道路整備の効果は勿論であるが, 大店法 (大規模小売店舗における小売業の事業活動の調整に 関する法律）の改正による規制緩和による影響が大き いものと思われる.

本研究では, 消費行動に関する意識構造分析と商業 地選択モデルの作成を行う目的で以下に示すような調 查を行った。なお，ここでは, 買い物目的地として 3 つの商業地区を取り上げている．1つは従来の商店街 である「高田駅前」であり，2つ目は「自宅周辺の商 店街」，そして 3 番目は「上越ウイングマーケットセ ンターに代表される郊外の大規模店舗」である.

(1)調查対象地区 : 図-1参照.

(2)調查内容 : 各商業施設の利用状況, 同行者, 交通 手段, 消費行動に関する意識調查（調査項目は表一 1参照），商業地選択モデル作成のための商業地間 の比較調查（調查項目は表-2参照）。

(3)調查年月 : 1996年7月に実施.

(4)調查方法 : 直接訪問配布・郵送回収方式を採用 （配布数2,000通，回収数 250 通）. 


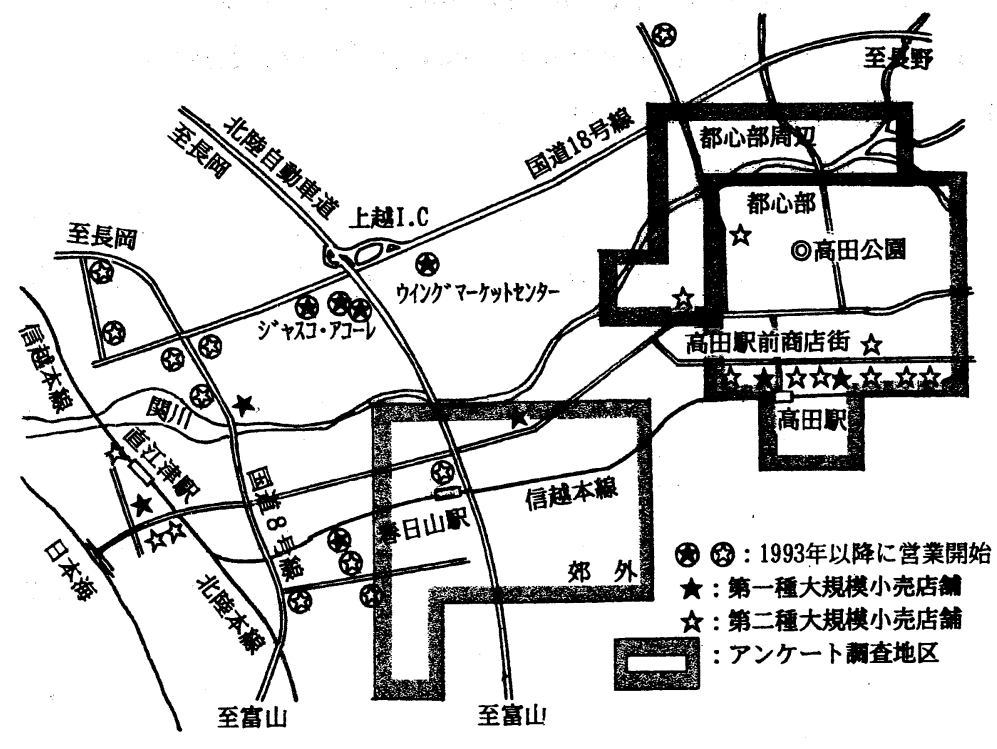

図-1 大規模店舗の立地状況

表一 1 消費行動に関する調查項目

\begin{tabular}{|c|c|}
\hline 号 & 問 \\
\hline 1 & 多少值段が高くとも，ブランド品の方が良い \\
\hline 2 & まとめ買いをして，買い物の回数を堿らしたい \\
\hline 3 & 駐車場からお店まではあまり歩きたくない \\
\hline 4 & バーゲンセールが好きである \\
\hline 5 & 1 力所の敷地内で色々なものを購入したい \\
\hline 6 & 食事やレジャーと併せて買い物をしたい \\
\hline 7 & 商店街のチラシを参考に買い物をする \\
\hline 8 & 食料品等は安ければメーカー名は気にしない \\
\hline 9 & 多少遠くても無料で広い駐車場のある所の方が良い \\
\hline 10 & 多少遠くても值段が安い方が良い \\
\hline 11 & 色々なお店が集まっている方が良い \\
\hline 12 & 㕢い物をする時はあまり歩きたくない \\
\hline 13 & できるだけ自宅付近のお店を利用したい \\
\hline 14 & 昔からの商店街を大事にしたい \\
\hline 15 & 色々な商品を見て歩くのが好きである \\
\hline 16 & 少々高くてもサービスの良い方が良い \\
\hline 17 & 欲しいものがある場合は，新渴や東京へも行きた \\
\hline 18 & 衝動買いをすることが多い \\
\hline 19 & 休日にはのっくりと買い物がしたい \\
\hline 20 & 自分が納得するまで品物を探す \\
\hline 21 & 嘪い物に行った時は飲食店に入るこ \\
\hline 22 & 生鮮食料品は価格よりも品質を重視する \\
\hline
\end{tabular}

回答: 1. 思わない 2. あまり思わない

3. 何とも言えない 4. やや思う 5. そう思う

表 -2 商業地間の比較項目

\begin{tabular}{|c|l|}
\hline 番号 & \multicolumn{1}{|c|}{ 比 較 項 目 } \\
\hline 1 & 生鮮食料品の安さ \\
\hline 2 & 生鮮食品の新鮮さ \\
\hline 3 & 商品全般の価格 \\
\hline 4 & 品揃えの豊富さ \\
\hline 5 & 店埔の種類 \\
\hline 6 & 取り扱つている品物の高級感 \\
\hline 7 & 子ども向けの㛟楽・遊技施設の充実 \\
\hline 8 & 駐車場の利用のしやすさ \\
\hline 9 & 自宅からの距離 \\
\hline
\end{tabular}

\section{3. 消費行動に関する意識棈造分析}

郊外型の大規模商業施設の急激な進 展は，消費者の消費行動に対する意識 の変化と無関係ではないものと思われ る.すなわち, 従来の買い物行動は， 単に必要な商品の購入を目的としてい たものが，最近では生活の潤いを求め るものとしての消費行動に変化しつつ ある. 西井等は ${ }^{3)}$ ，ショッピングコン プレックス来訪者の買物場所選択モデ ルの作成において，都心部の商店街と 郊外型大規模商業施設の比較を行って おり，駐車場の利用のし易さや交通渋 滞を除いて，両者の間にはそれほどの 違いは無いとしている，本章では，消 費者の買い物行動に対する意識構造を分析し，都心部 商店街と郊外型大規模店舗の差別化の可能性について 検討を行う。

図ー 2 は，表一 1 に示した22項目についての「こだ わり度」を図示したものである.ここで「こだわり度」 とは，各項目についての 5 段階評価「1.思わない， 2. あまり思わない，3.何とも言えない，4.pや思う， 5. そう思う」の結果に対し，「4と5の合計」から「1と2 の合計」を引いた比率を表している。従って，「こだ わり度」の值が大きいほど，その項目の質問内容と同 じような意識を持ち，逆に負の場合は反対の意識を持 っているものと考えられる。図から，「こだわり度」 の大きい項目としては，「11.色々なお店が集まって いる方が良い」「22.生鮮食品は価格よりも品質を重 視する」「3.駐車場からお店まではあまり歩きたくな い」等，消費者の買い物行動に対するこだわりが読み とれる.特に顕著なのは，「こだわり度」の高い項目 の多くは，郊外型の大規模店舗の特性そのものである ことである。

次に質問項目の回答結果に対して，因子分析を適用 し，消費者の類型化を行う. 図一 3 は，表- 1 に示し た22項目に対して，因子分析を適用し，因子負荷量の 值を図示した結果である（バリマックス回転後）。こ れらの結果から各因子軸を次のように定義した.

- 1 軸：「堅実型（納得型）」

- 2 軸 : 「正 : 近隣志向型」「負 : 郊外志㐰型」 


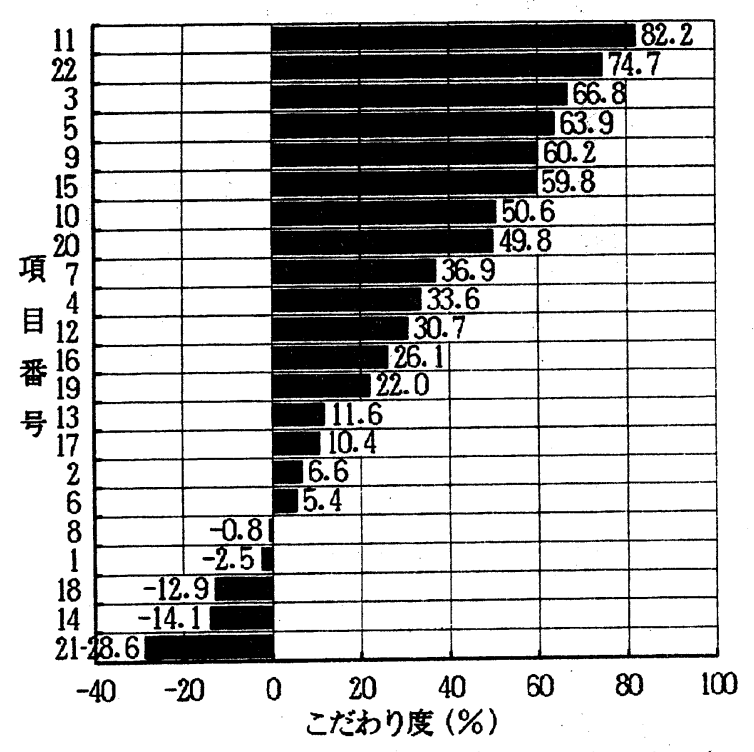

図ー2 消費行動のこだわり度（番号は表-1参照）

\section{-3軸：「駐車場重視型」}

・4 軸：「正 : 生活重視型」「負 : ブランド重視型」

・5軸：「レジャー重視型」

・6軸：「複合店舗重視型」

これらの各因子軸の解釈の中で， 2 軸の郊外志向型， 3 軸の駐車場重視型, 4 軸の生活重視型, 及び 5 軸と 6 軸は，いずれも郊外型の大規模店舗の特性であり， 因子軸にも顕著に現れていることが分かる.

図一 4 は，女性と男性の年代別の結果と家族の構成 人数による因子得点の平均値を図示したものである. なお全サンプルによる因子得点の平均値を各々 0.0 と しているため, 各グループ及び因子軸の得点の大小は 平均的な構造との差異, すなわち各グループの特徵を 表しているものと考えられる. 女性の年代別の結果か らは，29才以下の層は「堅実型（納得型）」「レジャ 一重視型」であり，39才以下では「郊外重視型」「駐 車場重視型」「レジャ一重視型」，40才以上では「近 隣志向型」「生活重視型」の特徵が現れている. 男性 はいずれも駐車場重視型であり，年代別では，29才以 下が「郊外志向型」「ブランド重視型」，39才以下で は「堅実型（納得型）」，40才以上はあまり特徵が見 られない。家族の構成人数別では，1人の場合は「堅 実型（納得型）」「郊外志向型」「ブランド重視型」 であり, 人数が多くなるに従って「近隣志向型」「駐 車場重視型」「生活重視型」となっていくことが分か
る.このことから郊外型大規模店舗の利用者層として 挙げられるのは，30才代の女性層である．この年代は 家族構成から見ても子育て世代であり, 郊外型大規模 店舗の利用は, 単に買い物目的だけではなく, 家族の レジャ一活動としての意味合いも高いものがある. 実 際に買い物を行う場合に同伴者をたずねた結果による と, 高田駅前や自宅周辺での買い物は, 1 人で行くこ とが多いが，郊外の場合には，家族主体での行動（い わゆるファミリー層) が特幑的な結果となった. 逆に 「堅実型 (納得型)」や「ブランド志向型」の購買層 を強調するならば，29才以下の独身層を対象としたよ うな店舗の充実が望まれる.

このように性別や年代, 家族構成により消費行動意 識に差異が見られるため, 商業地区の整備を行うに当 たっては, 地区毎にどのような差別化を行うかが重要 となる.次に具体的な購入品目の違いによる商業地区 の選択構造についての分析を行う。

\section{4. 品目別の商業地選択モデルの作成}

従来の商業地選択モデルは, 都心部か郊外かと言っ た場所のみを選択するモデルが主なものであり，大き く R P データに基づくモデルと S Pデータによるもの がある. また購入品目を考慮した場合でも, 最寄り品 と買い回り品程度の分類であり, 品目毎にモデル化を 行っているものは少ない.

本研究では, 消費者が買い物を行う場所として 3 カ 所の商業地区を設定していることは前述した通りであ る(都心部, 自宅周辺, 及び郊外型大規模店舗) . 図 一 5 は, 消費者が購入する品目毎にその購入場所をた ずねた結果を図示したものである. 例えば, 生鮮食品 は, 自宅周辺が最も高く全体の $67 \%$ 占め, 次いで郊 外の $29 \%$, 高田駅前の5\%となっている. 一方, 電化製 品やスポーツ用品は, 圧倒的に郊外での購入比率が高 く, 貴金属・時計等の高級品の購入に当たっては, 郊 外と高田駅前の購入比率が同じようになっている.こ のように購入する品目の特性によって, 消費者は購入 場所を変更していることが分かる. 従って, 商業地選 択モデルの作成に当たっては，このような購入品目の 特性を考慮できるようなモデル化が必要となるが, 従 来のような R P データに基づく方法ではモデル化が困 難であるため, ここでは S P データに基づくコンジョ 

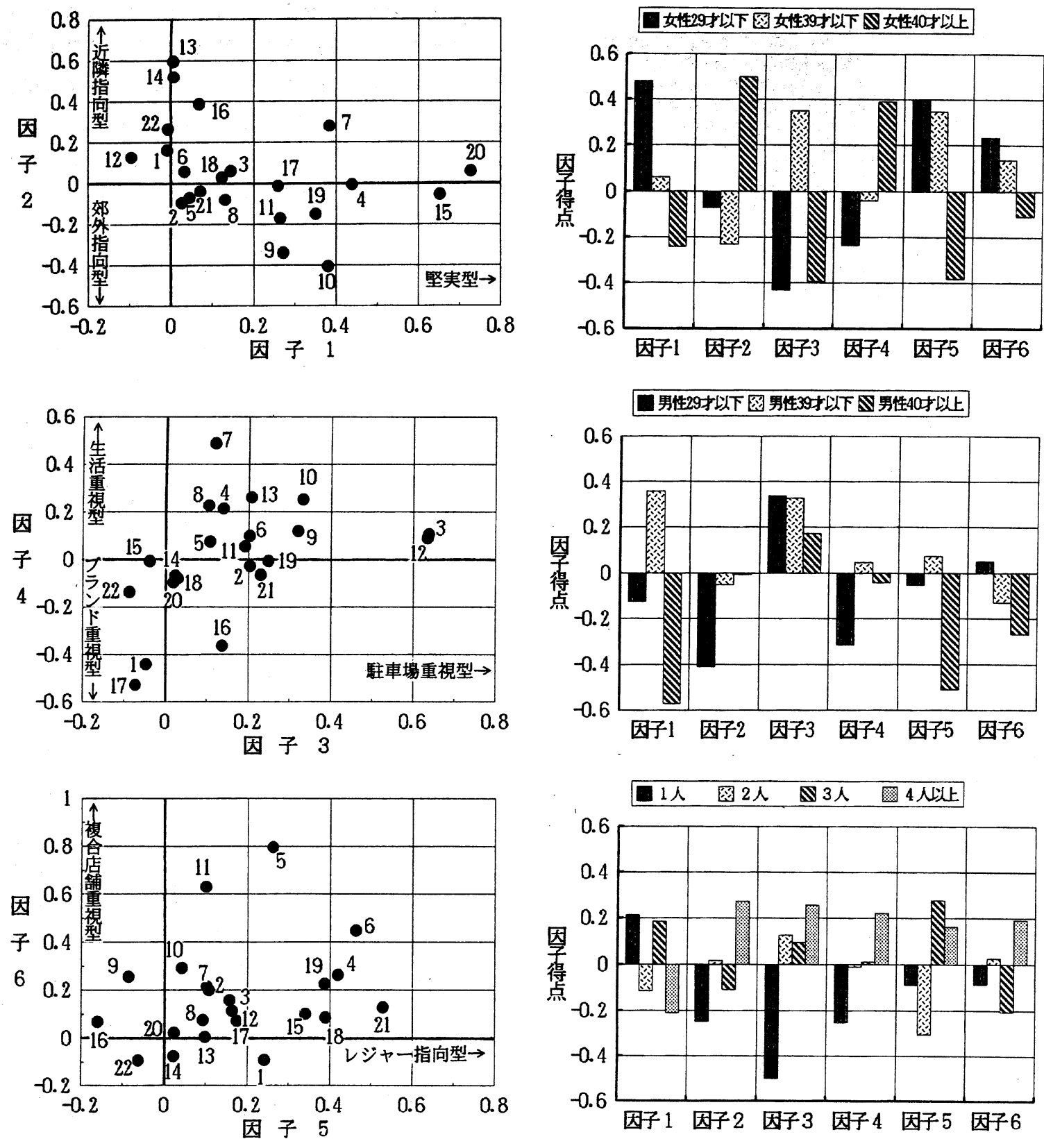

図－3 因子負荷量の分布（番号は表一 1 参照）

イント分析 ${ }^{4)}$ の適用を図った.コンジョイント分析で は，実験計画法に基づくフルプロファイル法が一般 的である.しかし, フルプロファイル法では, 選択 肢（品目毎の購入場所）と品目毎に属性値を設定し, 序列データの収集を行う必要があり, 考虑する品目 が多くなると, デー夕収集が困難となる，また属性 値の設定も定量的な要因が主となるため, 感覚的な 要因（定性的要因）を直接考慮することは出来ない

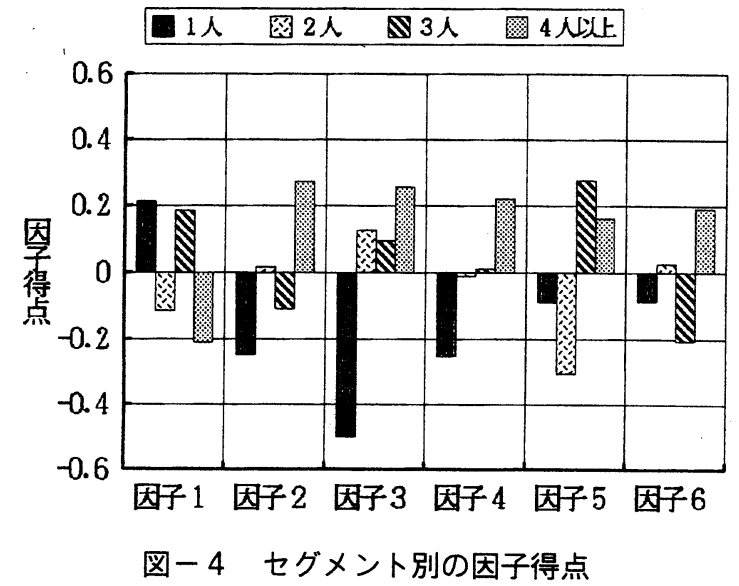

と言う問題がある．これらの問題点を回避するため, 本研究では選択肢（品目毎の購入場所）と属性值の 設定を別々に行った. モデル化の手順は以下の通り である。

(1) 表一 2 に示した要因毎に 3 力所の商業地区の比較 を A H P 手法により行い，要因別・商業地区別に属性 值を算出する，この場合，個人毎に得られた属性値の 整合度（C.I）が一定以上の場合は, 得られたデー夕 


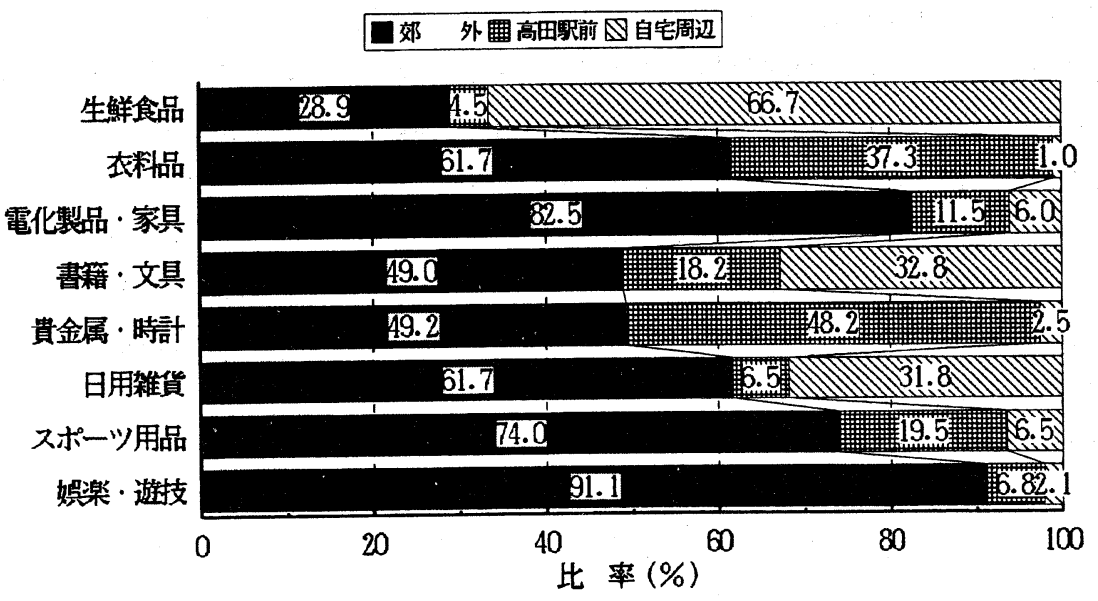

図ー5 品目別の購入場所
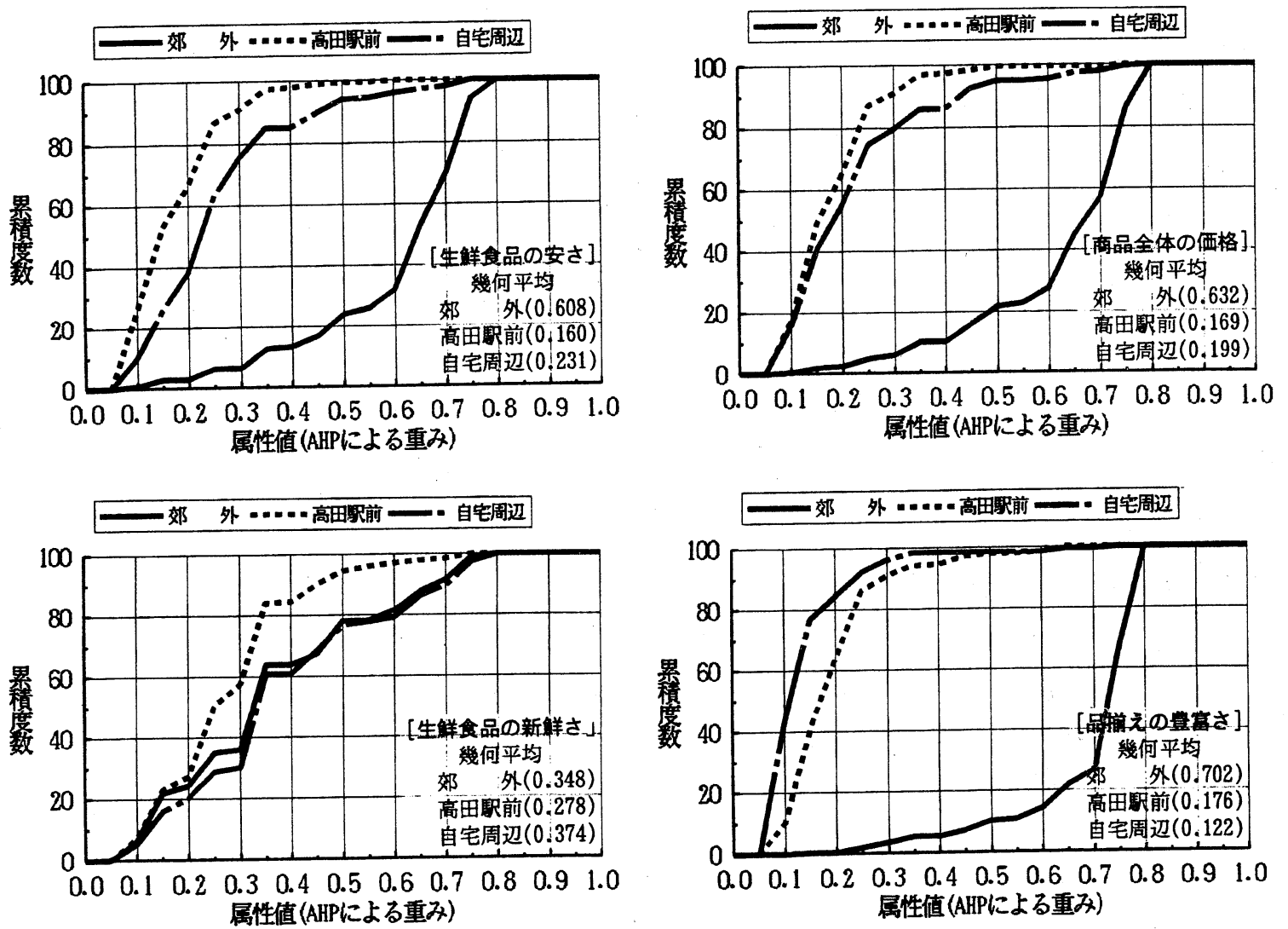

図-6 要因別属性値の累積度数分布

の信頼性が低いものと判断し, データから削除した.

(2) 図ー5に示した品目毎に購入したい場所を 3 力所

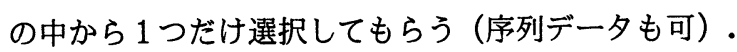
(3) (1)で求められた要因別・商業地別の属性値を説明 変数とし, (2)で選択された商業地の選択確率を最大
にするように効用関数を推定する．なお，効用関数の 推定には，非集計ロジットモデルを適用した。なお， (2)の序列データを用いる場合には，非集計ランクロジ ットモデルの適用も可能である.

図一6, 図一 7 は, A H P 手法により算出された要 
因別の属性值の累積度数分布を表したものである．例 えば,「生鮮食品の安さ」「商品全体の価格」「品揃 えの豊富さ」「店舗の種類」「遊技・娛楽施設」, 及 び「駐車場の利用」では, 圧倒的に「郊外」の属性値 の平均が高くなっているが，「品物の高級感」では 「高田駅前」が，また「自宅からの距離」では「自宅 周辺の商店街」の評価が高い結果となっている. また 「生鮮食品の新鮮さ」は，地域による差はあまり見ら れない，このように要因により，消費者は各商業施設 の評価を行っていることが分かる.

表一 3 は, 購入品目別の効用関数を表したものであ る.ここでは A H P 手法により要因別の属性值を設定 する場合, 全ての要因共, 正の值の方が効用が増大す るように設定しているため, 効用関数のパラメーター の値が負になる場合には，論理的に矛盾しているため， その要因は削除してある．表から明らかなように購入 品目により考慮している要因が異なっていることが分 かる. 例えば,「生鮮食品」の購入では,「生鮮食品
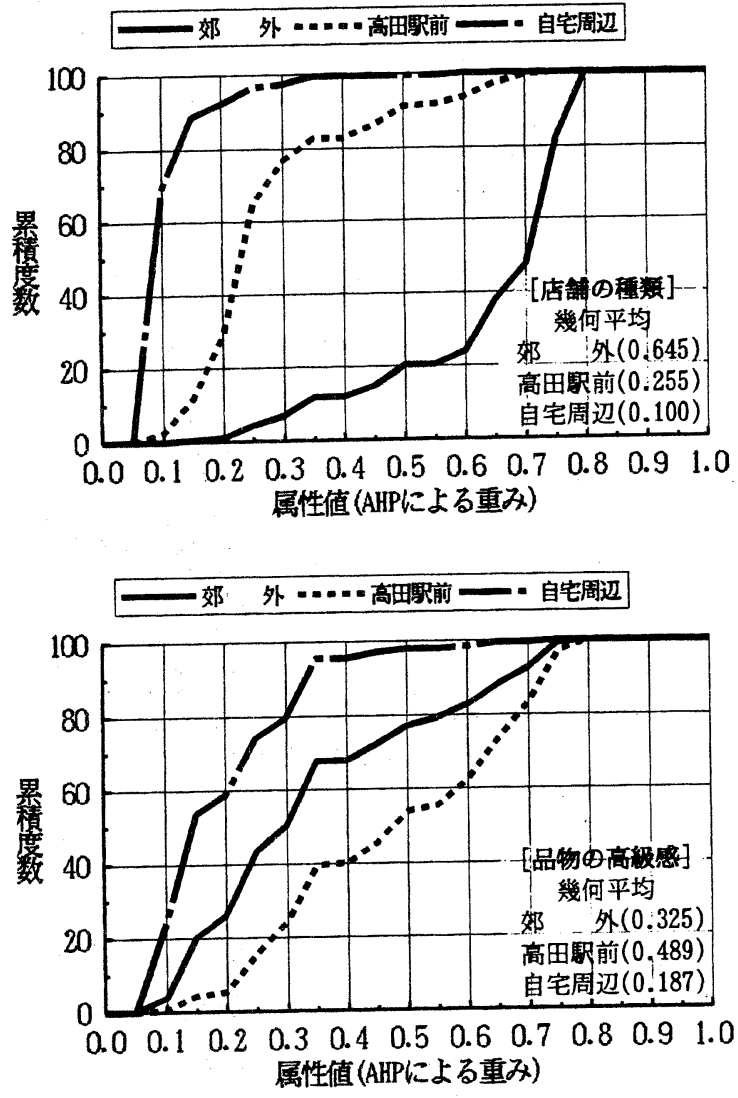

の安さ」「食品の新鮮さ」「自宅からの距離」が重 要な要因であり，「衣料品」や「貴金属・時計」の 購入では，「品物の高級感」が最も重要な要因であ ることが分かる。

郊外型大規模店舗の特徵である「品揃えの豊富さ」 や「娛楽・遊技施設」から見た場合には，購入品目 としては，「電化製品・家具」「スポーツ用品」及

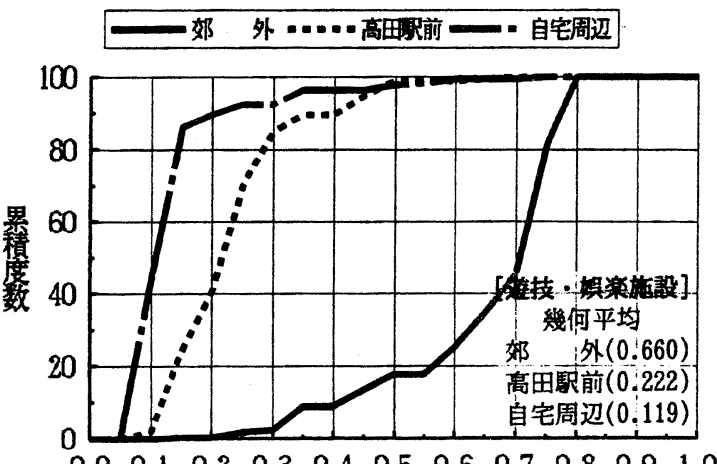

$\begin{array}{lllllllllll}0.0 & 0.1 & 0.2 & 0.3 & 0.4 & 0.5 & 0.6 & 0.7 & 0.8 & 0.9 & 1.0\end{array}$ 属性値(AHPによる重み)
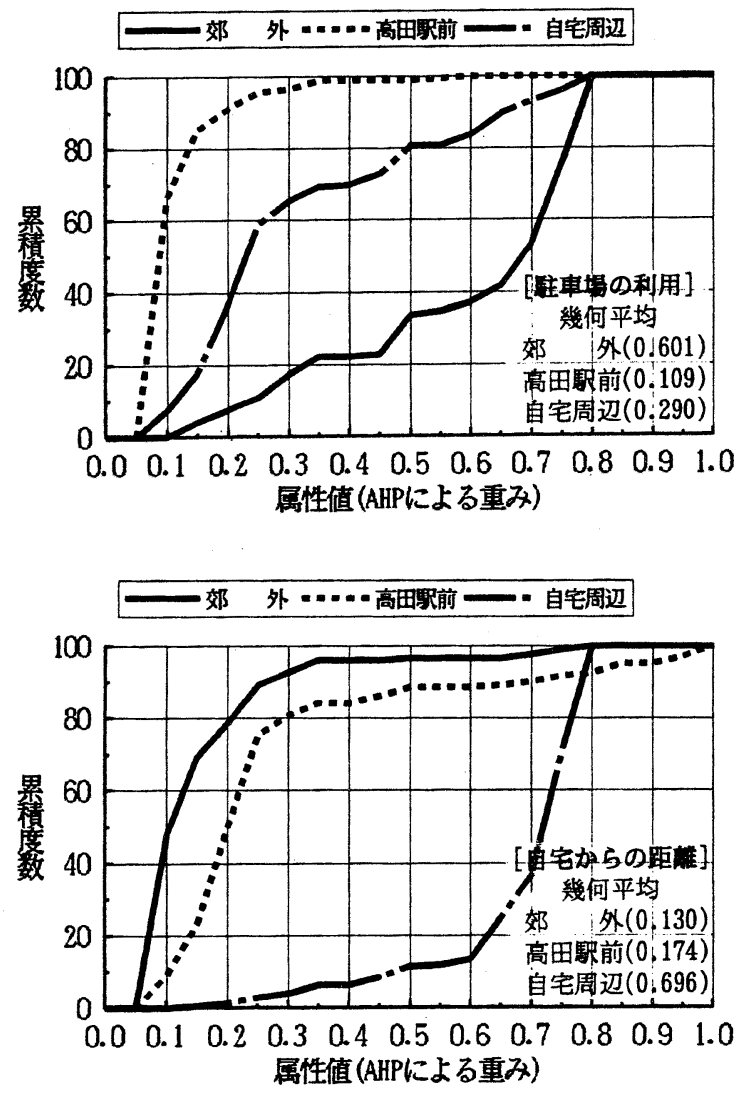
表 -3 購入品目別の効用関数

\begin{tabular}{|c|c|c|c|c|c|c|c|c|}
\hline 要 ${ }^{-}$購入品目 & 生鮮食品 & 衣 料品 & $\begin{array}{l}\text { 電化製品 } \\
\text { 家 县 }\end{array}$ & $\begin{array}{ll}\text { 書 } & \text { 籍 } \\
\text { 文 } & \text { 具 } \\
\end{array}$ & $\begin{array}{l}\text { 貫金属 } \\
\text { 時 計 }\end{array}$ & 日用雑貨 & \begin{tabular}{|l} 
スポーツ \\
用 品
\end{tabular} & \begin{tabular}{|l} 
娮 \\
遊 \\
\end{tabular} \\
\hline 生鮮食品の安さ & $\begin{array}{l}1.903 \\
(2.855)\end{array}$ & & & $\begin{array}{c}0.249 \\
(0.450) \\
\end{array}$ & & $\begin{array}{c}0.734 \\
(0.946) \\
\end{array}$ & & \\
\hline 食品の新鮮さ & 2.047 & $\begin{array}{c}0.531 \\
(1.018) \\
\end{array}$ & & $\begin{array}{c}0.628 \\
(1.439) \\
\end{array}$ & $\begin{array}{c}0.394 \\
(0.814) \\
\end{array}$ & & & $\begin{array}{c}0.922 \\
(1.077) \\
\end{array}$ \\
\hline 商品全体の価格 & & 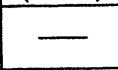 & $\begin{array}{c}0.497 \\
(0.738)\end{array}$ & & & $\begin{array}{c}1.960 \\
(2.569)\end{array}$ & & $\begin{array}{c}0.264 \\
(0.295) \\
\end{array}$ \\
\hline 品揃えの豊富さ & & $\begin{array}{c}1.165 \\
(1.753)\end{array}$ & $\begin{array}{l}1.888 \\
\text { (2. } 7292)\end{array}$ & $\begin{array}{c}0.674 \\
(1.149) \\
\end{array}$ & & $\begin{array}{c}0.440 \\
(0.706) \\
\end{array}$ & $\begin{array}{l}2.646 \\
\text { (4) }\end{array}$ & $\begin{array}{l}1.716 \\
(2.201)\end{array}$ \\
\hline 店 埔の種類 & & $\begin{array}{c}0.599 \\
(1.018) \\
\end{array}$ & $\begin{array}{c}0.888 \\
(1.329)\end{array}$ & & $\begin{array}{l}1.394 \\
(2.540)\end{array}$ & & A & 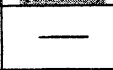 \\
\hline 品物の高級感 & & $\begin{array}{c}2.137 \\
(5.130)\end{array}$ & & & $\begin{array}{l}2.120 \\
(5.369)\end{array}$ & & $\begin{array}{c}0.962 \\
(2.086)\end{array}$ & \\
\hline 娛楽 - 遊技施設 & & $\frac{1.417}{(2.373)}$ & $\begin{array}{c}0.762 \\
(1.141)\end{array}$ & $\begin{array}{c}0.395 \\
(0.684)\end{array}$ & $\begin{array}{l}1.266 \\
(2.128)\end{array}$ & & $\begin{array}{c}0.506 \\
(0.873)\end{array}$ & $\begin{array}{c}4.245 \\
(5.40)\end{array}$ \\
\hline 駐車場の利用 & $\begin{array}{c}0.670 \\
(1.501)\end{array}$ & & $\begin{array}{c}0.780 \\
(1.586)\end{array}$ & $\begin{array}{c}0.821 \\
(2.061)\end{array}$ & & $\begin{array}{c}0.539 \\
(1.320) \\
\end{array}$ & $\begin{array}{c}0.578 \\
(1.279) \\
\end{array}$ & $\begin{array}{c}0.958 \\
(1.481) \\
\end{array}$ \\
\hline 自宅からの距離 & $\begin{array}{c}3.030 \\
(6.585)\end{array}$ & & & $\begin{array}{c}0.821 \\
(2.040)\end{array}$ & & $\begin{array}{l}1.183 \\
(2.636)\end{array}$ & & \\
\hline 无度比 & 0.336 & 0.307 & 0.460 & 0.107 & 0.209 & 0.228 & 0.363 & 0.696 \\
\hline 的中率 & 70.1 & 67.2 & 82.0 & 52.0 & 58.9 & 62.2 & 75.5 & 91.6 \\
\hline サソプル数 & 201 & 201 & 200 & 198 & 197 & 201 & 200 & 190 \\
\hline
\end{tabular}

（注）・( )内の数值は $\mathrm{t}$ 值，一は符号が論理的に合わないために削除，粼は $5 \%$ 有意水準を満足。

び「娛楽・遊技」が挙げられる。

また都心部の特徴である「品物の高級感」の観点 からは，「衣料品」と「貴金属・時計」のパラメー ターの值が大きくなっている．このことは，図ー4 にも示したように購買層として若年独身層をターゲ ットとした店舗展開を行うことにより商業施設間の 差別化の可能性を意味している.

このように消費者は, 購入する品目と各商業地区の 特徴を考虑して購入場所を決定していることから，商 業地区の差別化を行うためには，前述したように消費 者の属性による購買特性と, 本章の結果である購入品 目による要因別の重要性を勘案する必要がある.

\section{6. まとめ}

本研究は, 郊外型大規模店舗の中でもパワーセンタ 一と呼ばれる商業施設の立地による影響を，消費者の 意識構造分析と商業地選択モデルの作成を通して, 商 業地間の差別化について分析を行ったものである．得 られた主な結論は以下の通りである.

(1) パワーセンターの利用者の多〈は，いわゆる アミリ一層に属する世代が多く，買い物のみならずレ ジャー活動としての利用が認められた。このことから 従来の都心部の商業施設の活性化を考えるためには， 如何にして差別化を図るかであり，結果的には独身若
年層をターゲットとした戦略が不可欠である。

（2）従来の商業地選択モデルは, 都心部と郊外商業 施設の選択や最寄り品と買い回り品の選択と言ったモ デルが主であったが, 本研究で提案したように A H P 手法とコンジョイント分析を併用することにより，品 目別に商業地選択モデルの作成を行うことが可能とな り,より詳細な政策評価が可能である.

（3）購入品目別の商業地選択モデルの作成を行った 結果, 購入する品目と各商業地区の特性を考慮して購 入する場所を決定していることが明らかとなった。こ のことから商業地区間の差別化を行うには，取り扱う 品目の特性を十分に考慮した販売戦略が必要である.

\section{参 考 文 献}

1)浅野・瀬口：幹線道路沿線に集積する商業施設の立地構造 に関する基礎的研究，都市計画論文集，No30, PP. 169-174,1995

2)室町 - 原田・太田 : 都心商業地域の衰退状況と大規模小売 店舖の立地動向に関する研究, 都市計画論文集, №.29, pp. 529-534, 1994

3)西井・近藤・森川・弦間 : ショッピングコンプレックス来 訪者の買い物場所選択に関する意向分析, 都市計画論文 集, No.26-A,pp.283-288, 1991

4)湯沢・須田 : コンジョイント分析におけるプロファイルの 設定方法とその課題, 土木学会論文集, N0.518, pp.121-134,1995 
パワーセンター開業による消費行動の分析と商業地選択モデルの作成

湯沢 昭 ·渡辺愛子・須田 黙

従来の商業活動は, 駅前周辺の商店街を中心として繰り広げられてきたが, 近年では幹線道路沿線にそ の中心を移動しつつある.中でもパワーセンターと呼ばれる大規模複合商業施設の立地は, 消費者の購買 行動に大きな影響を与え, また消費行動の変化が商業施設の立地に対しても影響を与えている. 本研究は, 新潟県上越市を事例として, 郊外型大規模店舗の立地が消費行動に与える影響を分析し, その結果をもと に商業地選択モデルの作成を行い，従来の都心部の商店街と郊外型大規模店舗の差別化の可能性について 検討を行ったものである. その結果, 商業施設間の差別化を行うためには, 消費者の購買意識の分析と取 り扱う品目の特性を十分に考慮した販売戦略が必要である.

\section{Analyze of Consumer's Behavior and Make a Shopping District Choice Model considering an Effect of Power Center}

Akira YUZAWA, Aiko WATANABE and Hiroshi SUDA

The shopping activity are developed around the city center, but it will be transferring to the main road side. The large commercial complex facilitys which are called the power center give an effect on the consumer's behavior, and the change of the purchase actions give an influence on the location of the commercial facilitys. In this paper, we deal with the consumer's behavior by effects of the power center, and make the shopping district choice model which is to analyze the discrimination of the city center shops and the road side shops at Joetsu City in Niigata Prefecture in case study. 